\title{
Determining the Mechanical Characteristics of Composite Nanostructured Materials based on Recovered Silicone Rubber
}

\author{
POPESCU Daniel ${ }^{1, \mathrm{a}}$, CHERCIU Mirela $^{1, \mathrm{~b}}$, BUZATU Dumitru Ştefan $^{1, \mathrm{c}}$ and POPESCU \\ Roxana Cristina ${ }^{2,3, \mathrm{~d}}$ \\ ${ }^{1}$ University of Craiova, Romania \\ ${ }^{2}$ Politehnica University of Bucharest, Romania \\ 3 "Horia Hulubei" National Institute of Physics and Nuclear Engineering, Romania \\ adaniel.popescu1119@yahoo.com, ${ }^{b}$ mirela.cherciu2005@yahoo.com, ${ }^{\mathrm{c}}$ buzatu_stef@yahoo.com \\ droxana.popescu@nipne.ro
}

\begin{abstract}
This paper presents the mechanical characteristics of some nanocomposite materials based on recovered silicone rubber and different calcium carbonate nanopowders. The influence of the powders on the mechanical properties was studied by means of resistance at breakage, elongation at break and hardness.
\end{abstract}

\section{Introduction}

Recent research $[1,2,7,8]$ shows discovery of new materials based on recycled silicone rubber whose mechanical characteristics (e.g. longitudinal and transversal elasticity module) are far more superior to those of regular rubber [3-6, 9].

Using the same base matrix there were obtained variants of composite nanostructured materials by combining silicone rubber recovered from the coating of used composite electrical insulators with powders obtained from egg shells, snail shells and filtered conch.

\section{Determining The Mechanical Characteristics In Case Of Breaking Strain For Composite Nanostructured Material Based On Silicone Rubber Matrix}

The material used as base matrix was silicone rubber recovered from used silicone rubber from the coating of discarded $24 \mathrm{KV}$ composite electrical insulators in the form of silicone powder combined with liquid silicone rubber in different ratios and nanopowders obtained by recycling, yielding the following combinations:

In case of pure silicone rubber the results were: 
TABLE 1- EVALUATION OF MECHANICAL PROPERTIES (RESISTANCE AT BREAKAGE, ELONGATION AT BREAK AND HARDNESS) FOR SAMPLES OF PURE SILICONE RUBBER;

\begin{tabular}{|c|c|c|}
\hline $\begin{array}{c}\text { Resistance at breakage } \\
{\left[\sigma \mathrm{r} / \mathrm{daN} / \mathrm{cm}^{2}\right]}\end{array}$ & $\begin{array}{c}\text { Elongation at break } \\
{[\delta \mathrm{r} / \%]}\end{array}$ & $\begin{array}{c}\text { Hardness } \\
{\left[{ }^{\circ} \mathrm{shA}\right]}\end{array}$ \\
\hline 111 & 540 & 63 \\
\hline
\end{tabular}

Liquid silicone rubber (70\%) combined with silicone powder (30\%):

TABLE 2 - EVALUATION OF MECHANICAL PROPERTIES (RESISTANCE AT BREAKAGE, ELONGATION AT BREAK AND HARDNESS) FOR SAMPLES OF LIQUID SILICONE RUBBER $(70 \%)+$ SILICONE POWDER $(30 \%) ;$

\begin{tabular}{|c|c|c|}
\hline $\begin{array}{c}\text { Resistance at breakage } \\
{\left[\sigma \mathrm{r} / \mathrm{daN} / \mathrm{cm}^{2}\right]}\end{array}$ & $\begin{array}{c}\text { Elongation at break } \\
{[\mathrm{r} / \%]}\end{array}$ & $\begin{array}{c}\text { Hardness } \\
{\left[{ }^{\circ} \mathrm{shA}\right]}\end{array}$ \\
\hline 40 & 320 & 56 \\
\hline
\end{tabular}

Liquid silicone rubber $(68 \%)$ combined with silicone powder $(29 \%)$ and snail shell powder (3\%), (Fig. 1):

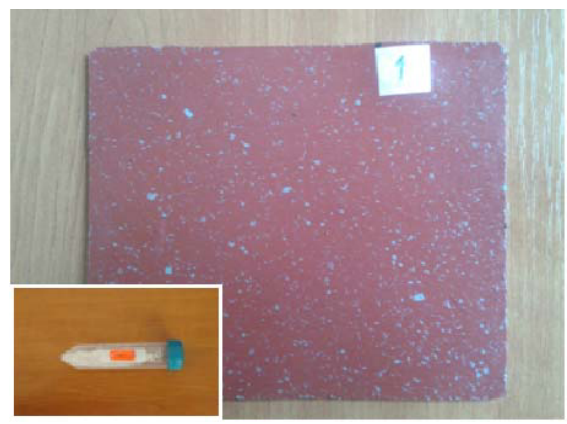

Fig. 1 - Technical plate from liquid silicone rubber $(68 \%)+$ silicone powder $(29 \%)+$ snail shell powder (3\%);

TABLE 3- EVALUATION OF MECHANICAL PROPERTIES (RESISTANCE AT BREAKAGE, ELONGATION AT BREAK AND HARDNESS) FOR SAMPLES OF LIQUID SILICONE RUBBER $(68 \%)+$ SILICONE POWDER $(29 \%)+$ SNAIL SHELL POWDER $(3 \%)$;

\begin{tabular}{|c|c|c|}
\hline $\begin{array}{c}\text { Resistance at breakage } \\
{\left[\sigma \mathrm{r} / \mathrm{daN} / \mathrm{cm}^{2}\right]}\end{array}$ & $\begin{array}{c}\text { Elongation at break } \\
{[\mathrm{r} / \%]}\end{array}$ & $\begin{array}{c}\text { Hardness } \\
{\left[{ }^{\circ} \mathrm{shA}\right]}\end{array}$ \\
\hline 38 & 300 & 60 \\
\hline
\end{tabular}

Liquid silicone rubber (68\%) combined with silicone powder $(29 \%)$ and filtered conch powder (3\%):

TABLE 4 - EVALUATION OF MECHANICAL PROPERTIES (RESISTANCE AT BREAKAGE, ELONGATION AT BREAK AND HARDNESS) FOR SAMPLES OF LIQUID SILICONE RUBBER $(68 \%)+$ SILICONE POWDER (29\%) + FILTERED CONCH POWDER (3\%);

\begin{tabular}{|c|c|c|}
\hline $\begin{array}{c}\text { Resistance at breakage } \\
{\left[\sigma \mathrm{r} / \mathrm{daN} / \mathrm{cm}^{2}\right]}\end{array}$ & $\begin{array}{c}\text { Elongation at break } \\
{[\delta \mathrm{r} / \%]}\end{array}$ & $\begin{array}{c}\text { Hardness } \\
{\left[{ }^{\circ} \mathrm{shA}\right]}\end{array}$ \\
\hline 29 & 260 & 57 \\
\hline
\end{tabular}

Liquid silicone rubber (68\%) combined with silicone powder (29\%) and egg shell powder $(3 \%)$ : 
TABLE. 5 - EVALUATION OF MECHANICAL PROPERTIES (RESISTANCE AT BREAKAGE, ELONGATION AT BREAK AND HARDNESS) FOR SAMPLES OF LIQUID SILICONE RUBBER $(68 \%)+$ SILICONE POWDER $(29 \%)+$ EGG SHELL POWDER $(3 \%)$

\begin{tabular}{|c|c|c|}
\hline $\begin{array}{c}\text { Resistance at breakage } \\
{\left[\sigma \mathrm{r} / \mathrm{daN} / \mathrm{cm}^{2}\right]}\end{array}$ & $\begin{array}{c}\text { Elongation at break } \\
{[\mathrm{\delta} \mathrm{r} / \%]}\end{array}$ & $\begin{array}{c}\text { Hardness } \\
{\left[{ }^{\circ} \mathrm{shA}\right]}\end{array}$ \\
\hline 36 & 340 & 59 \\
\hline
\end{tabular}

Research has determined the maximum amount of silicone powder absorbed by the liquid silicone rubber (liquid silicone rubber $42,6 \%$ and silicone powder 57,4\%):

TABLE 6 - EVALUATION OF MECHANICAL PROPERTIES (RESISTANCE AT BREAKAGE, ELONGATION AT BREAK AND HARDNESS) FOR SAMPLES OF LIQUID SILICONE RUBBER

\begin{tabular}{|c|c|c|}
\hline \multicolumn{4}{|c|}{$(42,6 \%)+$ SILICONE POWDER $(57,6 \%)$} \\
\hline $\begin{array}{c}\text { Resistance at breakage } \\
{\left[\sigma \mathrm{r} / \mathrm{daN} / \mathrm{cm}^{2}\right]}\end{array}$ & $\begin{array}{c}\text { Elongation at break } \\
{[\delta \mathrm{r} / \%]}\end{array}$ & $\begin{array}{c}\text { Hardness } \\
{\left[{ }^{\circ} \mathrm{shA}\right]}\end{array}$ \\
\hline 24 & 260 & 46 \\
\hline
\end{tabular}

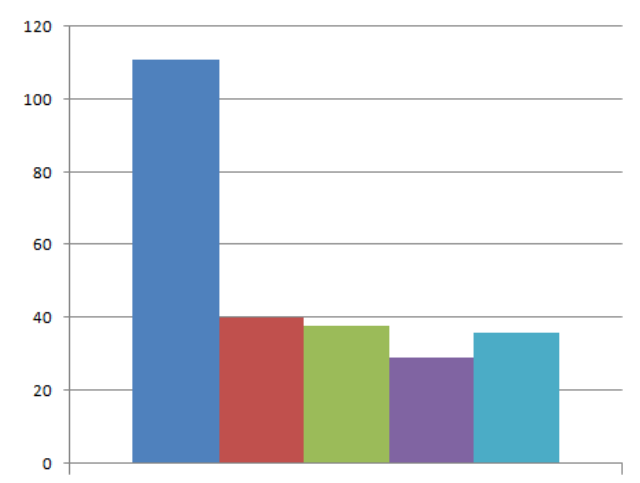

Resistance at breakage $\sigma \mathrm{r} / \mathrm{daN} / \mathrm{cm} 2$

pow recovered silicone
powder
30\% recovered silicone
powder
$29 \%$ recovered silicone
powder $+3 \%$ snail shell
powder
$29 \%$ recovered silicone
powder $+3 \%$ filtered
conch powder
$29 \%$ recovered silicone
powder $+3 \%$ egg shell
powder

Fig. 2- Resistance at breakage for samples with different percents of recovered silicone powder and nanopowder;

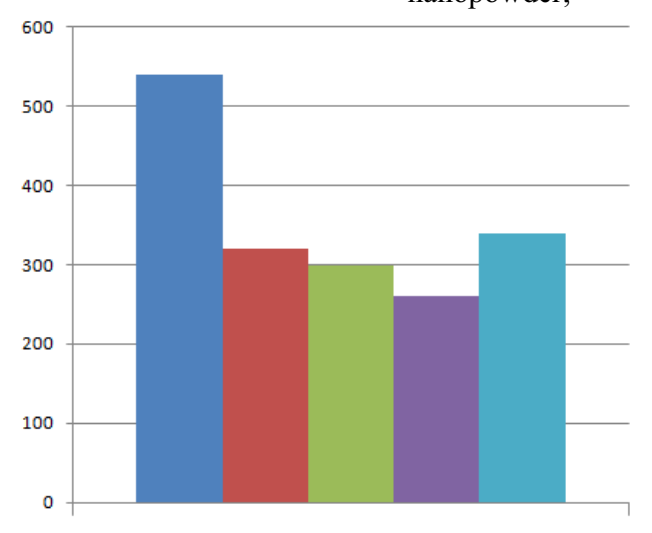

Elongation at break $\delta \mathrm{r} / \%$

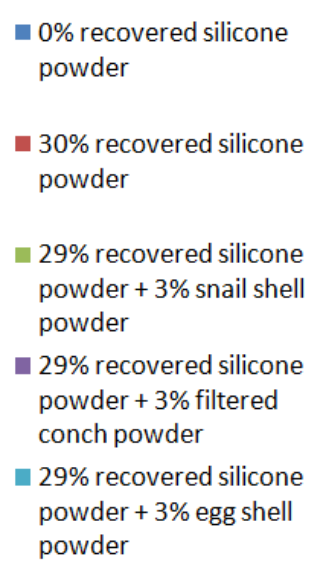
powder

Fig. 3- Elongation at break for samples with different percents of recovered silicone powder and nanopowder; 


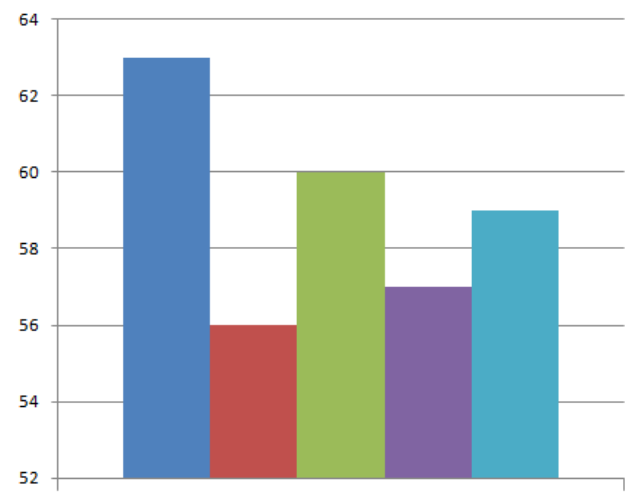

Hardness ${ }^{\circ}$ shA

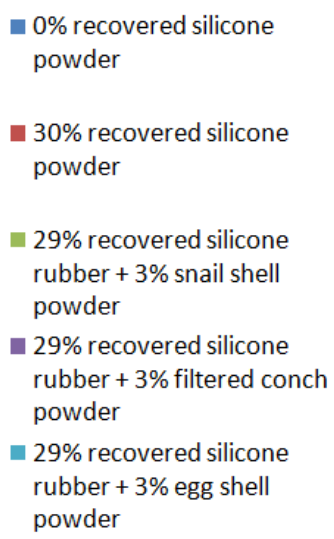

Fig. 4- Resistance at breakage for samples with different percents of recovered silicone powder and nanopowder;

The mechanical properties of the evaluated composite samples (resistance at breakage, elongation at break, respectively hardness) vary from the sample made of pure silicone rubber and $30 \%$ recovered silicone powder. The resistance at breakage decreases with the addition of the calcium carbonate nanoparticles, while the elongation at break increases for the case of egg shell powder. Regarding the resistance at breakage, the behavior is different: an increased hardness is recorded for all of the composite samples, the snail shell samples showing the best characteristics.

\section{Conclusions}

The new material is based on a matrix of silicone rubber recovered from $24 \mathrm{KV}$ composite electrical insulators.

The largest value of the unit breaking force or appears in case of "pure" silicone rubber, and decreases with the introduction of nanostructured components: snail shell powder 38 $\mathrm{daN} / \mathrm{cm}^{2}$, filtered conch powder $29 \mathrm{daN} / \mathrm{cm}^{2}$ and egg shell powder $36 \mathrm{daN} / \mathrm{cm}^{2}$.

Elongation at break $\delta \mathrm{r}$ also decreases from $540 \%$ in case of pure silicone rubber to $340 \%$ for the egg shell powder, $320 \%$ for silicone powder, $300 \%$ snail shell powder and $260 \%$ in case of filtered conch powder.

The measured hardness decreases from $63^{\circ} \mathrm{shA}$ (pure silicone rubber) to $57^{\circ} \mathrm{shA}$ (filtered conch powder), $59^{\circ} \mathrm{shA}$ (egg shell powder) and $60^{\circ} \mathrm{shA}$ (snail shell powder)

For the maximum combination of silicone rubber and silicone powder, the mechanical characteristics present minimum values: $\sigma \mathrm{r}=24 \mathrm{daN} / \mathrm{cm}^{2} ; \delta \mathrm{r}=260 \% ; \mathrm{D}=46^{\circ} \mathrm{shA}$.

\section{References}

1. D. Popescu, Investigation The Microstructure Of Silicone Rubber Recovered From Composite Electrical Insulators, Annals of the ORADEA UNIVERSITY , FASCICLE of MANAGEMENT and TECHNOLOGICAL ENGINEERING, XX( X), 4125-4129, (2011).

2. D. Popescu, Elements Regarding The Analysis Of Silicone Rubber Characteristics Obtined From Used Tile Of Electrical Composite Insulators, Annals of the ORADEA UNIVERSITY, FASCICLE of MANAGEMENT and TECHNOLOGICAL ENGINEERING, XI( XXI), no 1, 2106-2110, (2012). 
3. D. Popescu, R.C. Popescu, Regarding The Determination Of Viscoelastics Characteristics Of Recoverable Silicone Rubber, Annals of the ORADEA UNIVERSITY , FASCICLE of MANAGEMENT and TECHNOLOGICAL ENGINEERING, XI( XXI), no. 2, 280-284, (2012).

4. D. Popescu, M. Cherciu, Al. Stanimir, R.C. Popescu,- Regarding The Dynamic Characteristics Of Fiberglass Reinforced Epoxy Resin Rods Recovered From Used Composite Electrical Insulators, Proceedings of the Annual Session of Scientific Papers, IMT Oradea, XII ( XXII), 85-88, (2013).

5. D. Popescu, M. Zamfirache, D. St. Buzatu, R.C. Popescu, Regarding The Dynamic Charactristics Of Technological Products Obtained From Recycling Composite Insulators With Rubber Silicone Coating, Annals of the ORADEA UNIVERSITY, FASCICLE of MANAGEMENT and TECHNOLOGICAL ENGINEERING, XIII( XXIII), no. 1, 93-98, (2014).

6. R.C. Popescu, D. Popescu, A Correlation between Experimental Characteristics and Stress Analysis Modeling for Recycled Silicone Rubber, International Journal Of Engineering Sciences \& Research Technology, 3(7), 794-801, (2014).

7. D. Popescu, D. Şt. Buzatu, R. Gavrila, - Study Of Surface Roughness At Finishing Of Recovered Silicone Rubber, The $21^{\text {th }}$ INTERNATIONAL DAAAM SYMPOSIUM'INTELLIGENT MANUFACTURING \& AUTOMATION: FOCUS ON INTERDISCIPLINARY SOLUTIONS ‘', 0005-0007, ISSN 1726-9679, (2010),.

8. D. Popescu, M. Cherciu, Regarding The Characterisation Analysis Of Silicone Rubber Recoverable From Composite Electrical Insulator, International Conference On Manufacturing Scienece and Education, Sibiu, Romania, PROCEEDINGS, I, 75-79, (2011).

9. D. Popescu, R.C. Popescu, Regarding The Analysis Of Tension And Deformation State In Case Of Products Manufactured From Recovered Silicone Rubber, INTERNATIONAL CONFERENCE OF MECHANICAL ENGINEERING with the support of Romanian Academy of Technical Science, Craiova, Romania, Proceedings, Tome2, 503-506, (2013). 